\title{
YDS Arapça Sınavına Dair Bazı Tespit ve Öneriler (2013-2018)
}

Some Determinations and Suggestions Regarding YDS Arabic Exam (2013-2018)

\section{Abdullah Hacıbekiroğlu}

Dr. Öğr. Üyesi, Ankara Yıldırım Beyazıt Üniversitesi, İslami İlimler Fakültesi

Asst. Prof., Ankara Yıldırım Beyazıt University Faculty of Islamic Studies, Ankara/Türkiye

E-Posta: ahacibekiroglu@ybu.edu.tr

ORCID: 0000-0002-1495-9728

\section{Muhammet Mücahit Asutay}

Dr. Öğr. Üyesi, Ankara Yıldırım Beyazıt Üniversitesi, İslami İlimler Fakültesi Asst. Prof., Ankara Yıldırım Beyazıt University Faculty of Islamic Studies

E-Posta: mucahitasutay@hotmail.com

ORCID: 0000-0003-3200-4666

\section{Makale Bilgisi | Article Information}

Makale Türü / Article Type: Araştırma Makalesi/ Research Article

Geliş Tarihi / Date Received: 12 Ekim/October 2021

Kabul Tarihi / Date Accepted: 29 Kasım/ November 2021

Yayın Tarihi / Date Published: 15 Aralık/15 December 2021

Yayın Sezonu / Pub Date Season: Kış-Aralık/ Winter-December

DOI: $10.46595 /$ jad.1008468

Cite as / Atıf: Hacıbekiroğlu, Abdullah-Asutay, M. Mücahit. “YDS Arapça Sınavına Dair Bazı Tespit ve Öneriler (2013-2018)", Journal of Analytic Divinity 5/3 (Aralık/December 2021), 112-130.

İntihal/Plagiarism: Bu makale, iThenticate yazılımınca taranmıştır. İntihal tespit edilmemiştir. This article has been scanned by iThenticate. No plagiarism detected.

Etik Beyan/Ethical Statement: Bu çalışmanın hazırlanma sürecinde bilimsel ve etik ilkelere uyulduğu ve yararlanılan tüm çalışmaların kaynakçada belirtildiği beyan olunur/It is declared that scientific and ethical principles have been followed while carrying out and writing this study and that all the sources used have been properly cited (Abdullah Hacıbekiroğlu-M. Mücahit Asutay)

Finansal Destek / Grant Support: Yazarlar bu çalışma için finansal destek almadıklarını beyan etmiştir. / The authors declared that this study has received no financial support.

CC BY-NC 4.0 | This paper is licensed under a Creative Commons Attribution-NonCommercial License

Çıkar Çatışması / Conflict of Interest: Yazarlar çıkar çatışması olmadığını beyan etmiştir. / The authors declared that there is no conflict of interest.

Yazar Katkıları / Author Contributions: Abdullah Hacıbekiroğlu \%55, M. Mücahit Asutay \%45

Web: http:/ / dergipark.org.tr/jad | e-mail to: editorjand@gmail.com 
Öz

Bu çalışmada ÖSYM'nin yapmış olduğu yabancı dil sınavlarından biri olan YDS Arapça sınavı ele alınmıştır. Bu inceleme ÖSYM'nin resmî internet sitesinde yayınladığı 2013-2018 arasındaki YDS Arapça sınav soruları ile sınırlandırılmıştır. 2013-2018 yılları arasında toplam on iki sınav yer almaktadır. Bu sınavdaki sorular önce harekelenen kelimeler açısından incelemeye tabi tutulmuştur. Harekelemenin hangi ölçütlere göre yapıldı̆̆ı araştırılmıştır. Hangi kelimelerin harekelenmesi gerektiğine dair öneriler sunulmuştur. Daha sonra sorular yazım hataları açısından incelenmiş ve tespit edilen hususlara dikkat çekilmiştir. Sorulardaki bazı dilbilgisi hatalarına da vurgu yapılmıştır. Çeviri sorularıyla ilgili bazı değerlendirmeler sunulmuştur. Adayın yabancı dil düzeyini yeteri kadar ölçmediği düşünülen bazı sorularla ilgili eleştiriler yöneltilmiştir. Soru kitapçı̆̆ındaki biçimsel kusurlara da işaret edilmiştir. YDS sınavına lisansüstü eğitime başvurmak isteyen adaylar, yabancı dil tazminatı almak isteyen kamu personelleri, doçent adayları, doktora ve sanatta yeterlik çalışmasına başvuracak olanlar, tıpta uzmanlık yapmak isteyen doktorlar, öğretmenlik atamalarında kullanmak üzere bazı yabancı dil öğretmen adayları, öğretim üyesi dışındaki öğretim elemanı kadrosuna başvurmak isteyen adaylar girmektedir. Bu yüzden sınavdaki hataların asgari düzeye indirilmesi gerekir. Bu çalışma yukarıda zikredilen hususlar çerçevesinde YDS Arapça sınavına içerik ve şekil bakımından bazı standartların belirlenmesine katkı sunmayı hedeflemektedir.

Anahtar Kelimeler: Arapça, YDS Sınavı, Yazım Hataları, Dilbilgisi Hataları, Çeviri Hataları.

\begin{abstract}
In this study, YDS Arabic exam, which is one of the foreign language exams given by ÖSYM, is discussed. This review is limited to the YDS Arabic exam questions between 2013-2018 published on the official website of ÖSYM. There are twelve exams in total between 2013-2018. Firstly, the questions in this exam were examined in terms of use of symbols (haraka) in words. It was investigated according to which criteria the use of symbols was made. Suggestions were made on which words should use symbols. Afterwards, the questions were examined in terms of spelling mistakes and attention was drawn to the detected issues. Some grammatical mistakes in the questions were also emphasized. Some evaluations about the translation questions are presented. Reviews were directed towards some questions that were thought to not adequately measure the candidate's foreign language level. Formal flaws in the question booklet were also pointed out. Who want to apply for graduate education, civil servants who want to receive foreign language compensation, candidates for associate professors, those who will apply for doctorate and proficiency in art, doctors who want to specialize in medicine, some foreign language teacher candidates, who want to apply for teaching staff except faculty members. He takes the YDS exam. Therefore, mistakes in the exam should be minimized. This study aims to contribute to the determination of some standards in terms of content and form for the YDS Arabic exam within the framework of the above-mentioned issues.
\end{abstract}

Keywords: Arabic, YDS Exam, Spelling Mistakes, Grammar Mistakes, Translation Mistakes. 


\section{Giriş}

ÖSYM tarafından yapılan sınavlardan biri de Yabancı Dil Sınavı (YDS)'dır. Bu sınav İngilizce, Almanca, Fransızca vd. batı dillerinden yapıldığı gibi Arapça, Farsça gibi doğu dillerinden de yapılmaktadır. YDS Arapça sınavı ilkbahar ve sonbahar olmak üzere yılda iki kez uygulanan bir sınavdır. Lisansüstü eğitime başlamak isteyenler, akademisyenler ve kamu personeli gibi önemli bir kesim yabancı dil seviyesini belirlemek üzere bu sinava girmektedir. 2013 yılından önce KPDS ve ÜDS adıyla uygulanan yabancı dil sinavları bu tarihten itibaren YDS olarak uygulanmaya başlamıştır. Daha önce 100 olan soru sayısı YDS ile 80'e düşürülmüştür.

2006-2012 yıllarına ait KPDS soruları ÖSYM'nin resmî internet sayfasında yayınlanmıştır. 2013-2018 YDS soruları da aynı şekilde internet sayfasında yayınlanmış olup 2018' den sonra soruların sadece yüzde 10'luk kısmı Temel Soru Kitapçıkları adı altında yayınlanmaktadır. ${ }^{1}$ Ancak sınav bitiminden kısa bir süre sonra sorular, sınava giren adaylar için açılmaktadır. Böylece ÖSYM tarafından adaylara soruları belli bir süreliğine inceleyebilme imkânı sağlanmaktadır.

YDS Arapça sınavı ile ilgili yapılan literatür taramasında "YDS Arapça Üzerine Eleştirel Bir Değerlendirme" 2 başlıklı makale dışında herhangi bir yayına rastlanamamıştır. Çalışmamız söz konusu makaleden bazı başlıklar ve tüm örnekler açısından farklılık arz etmektedir. Araştırmamızda 2013-2018 arasındaki YDS Arapça soruları incelemeye tabi tutulmuştur. Makale, altı başlıktan oluşmaktadır. Önce sınavlardaki hareke ve sembol kullanımı konusu ele alınmış; tenvin kullanımı, sülâsî fiillerin harekelenmesi, meçhul fiillerin harekelenmesi gibi konularda tespitler yapılmış ve öneriler sunulmuştur. Daha sonra yazım hataları incelenmiştir. Çok kullanılan edatlardaki yazım hataları, hemzenin yazılışı, yabancı kelimelerin yazımı gibi konular açısından sınav soruları gözden geçirilmiş bazı tespit ve tavsiyelerde bulunulmuştur. Daha sonra ise dilbilgisi hataları, çeviri hataları, şekilsel kusurlar gibi başlıklar altında ilgili konular inceleme ve değerlendirmeye tabi tutulmuştur.

\section{Hareke ve Sembol Kullanımı}

ÖSYM'nin yapmış olduğu yabancı dil sınavları arasında YDS Arapça sınavı bir yönüyle diğer dil ve sınavlardan ayrılmaktadır. Sessiz harflerden oluşan Arap dilinin okunabilmesi için 'hareke' adı verilen semboller ve bazı med işaretleri kullanılmaktadır. Farklı biçimlerdeki bu semboller sessiz harfleri seslendirmektedir. Arap dili ile ilgili klasik veya modern literatüre bakıldığında bu sembollerin çokça kullanılmadı̆̆ı göze

\footnotetext{
1 bk. ÖSYM, “YDS Çıkmış Sorular” (Erişim 04 Eylül 2021).

2 bk. Osman Aktaş, "YDS Arapça Üzerine Eleştirel Bir Değerlendirme”, Bozok Üniversitesi İlahiyat Fakültesi Dergisi 19/19 (Haziran 2021), 147-167.
} 
çarpmaktadır. ${ }^{3}$ Metinlerin büyük çoğunluğu ya harekelenmemiş veya kısmen harekelenmiştir. ${ }^{4}$ Arapça dil metinlerinin genel hâli böyle olduğu için bu dille ilgili bir sınavda bu genel durumun göz önünde bulundurulması doğaldır. Ancak sessiz harflerden oluşan bir alfabede farklı okuma ihtimalleri her zaman pek çok kelime türü için geçerliliğini devam ettirmektedir. Dili iyi düzeyde bilenler bile farklı okunma ihtimali olan kelimelerde yanılabilirler. Bu durum da anlamsal hatalara yol açabilir. Kelimelere gramatik görevinin bazı cümle veya metinlerde görülebilmesi için belli oranda son harfinin harekesi de konulabilir.

2013-2018 yılları arasında yayınlanmış YDS Arapça soruları incelendiğinde belli düzeyde harekelendirmenin yapıldığı görülmektedir. Özellikle sonu mansub olan kelimelerde iki üstün ve diğer bazı kelimelerde de şeddenin yaygın bir şekilde kullanıldığı görülmektedir. Ayrıca bazı meçhul fiiller de harekelenmiştir. Bazen de kelimenin gramatik görevini gösteren son harfin harekelendiği de görülmektedir. Ancak tüm bu tabloya bakıldığında ortak ilkeler göz önünde bulundurularak veya bir standart çerçevesinde hareke kullanımı yapılmadığı rahatlıkla söylenebilir. Buradan hareketle makalede şu soruların cevapları verilmeye çalışılacaktır: Soru metinlerinde hareke kullanılabilir mi? Yoksa kesinlikle hareke kullanımı yapılmamalı mı? Kullanılacaksa eğer harekelerden ne düzeyde yararlanılmalı? Önceki sorularda hiç hareke kullanımı olmuş mudur?

\section{1. İki Üstün/Tenvin Kullanımı}

Arapça bir metni okuma kolaylığı sağlayan harekelerin bu sınavda adayın okumasına pek fazla katkı sağlamadığı görülmektedir. Örneğin sonu uzatma elifi ile biten kelimelere genellikle tenvin konulmuştur. Tenvin de çoğunlukla kelimenin son harfinin üzerine değil elifin üzerine yazılmıştır. Oysa harekenin ilgili harfin üzerine gelecek şekilde yapılması daha uygundur. Şayet harekelerden yararlanmak gerekiyorsa hem anlamı hem de okumayı kolaylaştıracak kritik yerlerin harekelenmesi daha münasip olur. YDS Arapça sınavlarında ise harekeler, kullanılması gereken yerlerde kullanılmamıs, kullanılmaması gereken yerlerde ise bolca kullanılmıştır.

Tenvin bazen kelimenin sonundaki elifin üzerine konulmuş bazen de eliften önceki harfin üzerine konulmuştur. Ekseriyeti ise elif üzerinde görünmektedir. Bu yüzden iki üstünün kullanımında iki yoldan biri tercih edilerek yazımda tutarlılık sağlanmalıdır. Meselâ aşağıdaki örnekte tek soruda iki farklı harekeleme dikkat çekmektedir:

2013-YDS İlkbahar 8. Soru:

$$
\text { عاش في الصحراء حرًا كالهواء، ---- كالطير، أبيّاً كالأسد، قوي القلب كالصخر. }
$$

\footnotetext{
${ }^{3}$ Kur'ân-1 Kerîm, sözlükler ve dil öğretim setleri hariç.

4 Ernst Harder, Gaspey-Otto-Sauer Metodu: Modern Arapça Grameri, çev. Ekrem Sarıkçığlu (İstanbul: Otağ Yayınları, 1982), 10.
} 

A) مقيداً
B) طليقاً
C) معزjاً
D) تليداً
E) طريفاً

Cümlede geçen $\xi^{\prime}$ kelimesinde tenvin eliften önceki râ harfine, soru kökündeki ve şıklardaki diğer kelimelerde ise elifin üzerine konulmuştur.

Diğer bir husus, Arap dilinde sonunda elif olan kelimelerin büyük bir çoğunluğu üstün tenviniyle okunmaktadır. Oysa Arapça yabancı dil sınavlarında buna benzer hemen hemen bütün kelimelere tenvin konulmaktadır ki, bu kanaatimizce okuyucuya çok da yarar sağlamamaktadır. Dolayısıyla bu tür kelimelere tenvin konulmaması daha uygundur. Eğer tenvin konulacaksa da yukarıda değinildiği gibi bir tutarlılık içerisinde yazılmalıdır.

Ayrıca nâkıs fiillerin ism-i fâillerinde esre tenvini konulması adayın kelimeyi doğru okumasına katkı sağlayacak ve yanlış okumaların önüne geçecektir. Örneğin 2013-YDS İlkbahar sınavının 13. sorusundaki كاف tamlamasındaki كاف talimesi nâkıs كفى fiilinin ism-i fâilidir. Elif lâmsız yazıldığında hazfedilen yâ harfinin yerine getirilen tenvinle كاف كَّل şeklinde okunmalıdır. ${ }^{5} \mathrm{Bu}$ duruma işaret etmesi için de tenvinli yazılmalıdır. ${ }^{6}$ Aksi takdirde ecvef bir fiil gibi okunması söz konusu olabilir. Bu durum adayın kelimeyi dolayısıyla cümleyi yanlış anlamasına yol açabilecektir. Nitekim bu husus, 2013-YDS-İlkbahar خالٍ المسرح السياسي العراقي خالٍ من نوابغ وعباقرة " ifadesinde kelimesinin iki esreyle belirtilen şekilde harekelendiği görülmektedir.

\subsection{Sülâsî Fiillerin Harekelenmesi}

YDS Arapça sınavlarının bazı sorularında sülâsî malum fiillerin harekelendiği diğer bir kısmının ise harekelenmediği görülmektedir. Örneğin 2018-YDS Sonbahar 51-54. sorulara ait paragrafta fiilinin 'ayne'l-harfi harekelenmiştir. Ancak başka malum fiiller ise çoğunlukla harekelenmediği gözlenmektedir. Dolayısıyla bu tür fiillerin hangi ölçüte göre harekelendiği net değildir. Malum sülâsî fiilleri harekelemenin okuyucuya çok da katkı sağlamayacağı açıktır. Ancak mezîd bablardan gelip sülâsî ile karışması mümkün olan fiillerin harekelenmesinde fayda mülâhaza edilmektedir. Bu da en çok if'âl babında ortaya çıkmaktadır. Örneğin 2014-YDS İlkbahar 73. soru metnindeki “ ويجب على الأم خلال فترة الحمل تعد fiili if'âl babından kullanılmıştır. Bu fiilin ilk harfi harekelenmediği için sülâsî bir fiil olarak da düşünülmesi olasıdır. Eğer fiil ötre ile harekelenirse okuyucu metni daha rahat anlayabilecek ve diğer fiillerle karıştırmayacaktır.

\footnotetext{
5 Ebü'l-Feth Osmân b. Cinî el-Mevsılî İbn Cinnî, Şerhu't-Tasrîfi'l-mülûkî, thk. Dîzîrîh Sakkal (Beyrut: Dârü'1fikri'l-Arabî, 1419/1998), 45; Ahmed el-Hamlâvî, Şeze'l-arf fî fenni's-sarf (Riyad: Mektebetü'l-maârif, 2001), 66; Abduh er-Râcihî, et-Tatbîku's-sarfì (Beyrut: Dârü'n-nehdati'l-Arabiyye, 1393/1973), 76; Hüseyin Tural, Temel Sarf Bilgileri (İstanbul: Ensar Neşriyat, 2011), 191.

${ }^{6}$ Hüseyin Günday, “Arapça-Türkçe Leksikografiye Dair Bir Tenkit Yazısı: Serdar Mutçalı'nın Arapça-Türkçe Sözlük Örneği”, Uludă̆ Üniversitesi İlahiyat Fakültesi Dergisi 21/2 (Haziran 2012), 156.
} 
2015-YDS İlkbahar 31. soru E seçeneğindeki “ يطروننا "الناس يطروننا في كل مكان" cümlesinde geçen fiili hem az kullanılan bir fiildir hem de burada if âl babından kullanılmıştır. Arap dili uzmanlarının bile bu ifadeyi okuyup anlamlandırmada zorlanacağ nedenle kelimenin okunabilmesi için kritik harfin harekelenmesinin faydalı olacağ 1 mülâhaza edilmektedir. Böylece değişik şekillerde okunmaya elverişli olan kelimenin diğer okuma biçimlerinden sıyrılıp doğru bir şekilde okunabilmesi sağlanacaktır. Ayrıca bu fiil

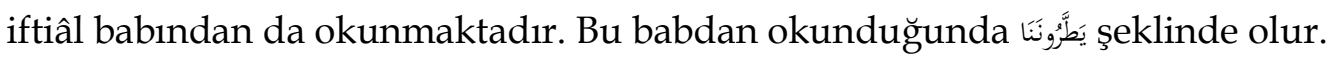

\subsection{Meçhul Fiillerin Harekelenmesi}

Yukarıda malum muzâri için zikredilen durumlar meçhul muzâri için de geçerlidir. Örneğin يعد ve يترك fiilleri bir taraftan;

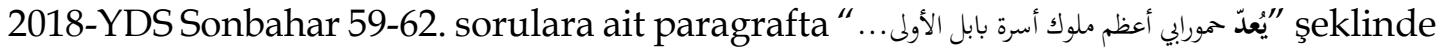
başlayan cümlede fiili,

2016-YDS İlkbahar 59. soru C seçeneğindeki “ضررها أكثر من ضرر الأشعة السينة ولذلك يُّكَك استعماها" cümlesinde de يُّرك fiili meçhul okunuşa göre harekelenmiştir.

Diğer taraftan meçhul fiillerin bazı sorularda ise harekelenmediği müşahade edilmektedir. Örneğin 2016-YDS İlkbahar 41. soru C seçeneğindeki “ حكم بنو ساسان على بلاد فارس في cümlesinde yer alan fiili harekesiz verilmiştir.

Meçhul fiillerin harekelenmesi malum fiillere göre daha fazla önem arz etmektedir. Meçhul fiiller harekelendiğinde okuyucunun karşılaşabileceği yanlış okuma hataları ortadan kaldırılmış olur. Ancak burada da bir standart belirlenmesi gereklidir. Sülâsî meçhul fiillerde orta harfin, mezîd fiillerde sondan bir önceki harfin harekelenmesi ilke olarak benimsenebilir. Buna benzer işlevsel hareke kullanımının hem dil öğrenimi hem de sınavlara giren adaylar için önemli katkı sağlayacağı düşünülmektedir.

Ayrıca mezîd babların ism-i fâil ve ism-i mef' $\hat{l}$ l formunu birbirinden ayıran temel ölçüt sondan önceki harfin fethalı veya kesreli okunmasıdır. Bu sorun ism-i fâil olan kelimede kesrenin, ism-i mef' ûl olan kelimede ise fethanın konulması ile ortadan kaldırılıp adayları hem ikileme düşmekten kurtaracak hem de süre yarışında kendilerine hız kazandıracaktır.

\section{4. İsimlerle İlgili Hareke Önerileri}

Aşağıdaki soruda قصص kökü bazen قِصَص bazen de قَصَص şeklinde harekelenmiştir.

2013-YDS Sonbahar 39. Soru: 
Şehrazad'ın, Kral Şehriyar'ın huzurunda kız kardeşi Dünyazad'a anlattığı Binbir Gece Masalları, hayal gücünün hâkim olduğu bir halk hikâyeleri derlemesidir.
A) قِصَص ألف ليلة وليلة، التي تحكيها شهرازاد لأختها دنيازاد في حضرة الملك شهريار، بجموعة من القَصَصص الشببي، يغلب عليها طابع الخيال.
Bن تعلب قوة الخيال على قِصَص ألف ليلة وليلة، وهي مجموعة حكايات تحتوي على ما تقصها شهرازاد لأختها دنيازاد في حضرة الملك شهريار.
Cِصَص ألف ليلة وليلة، التي يسودها طابع خيال شعبي، هي مجموعة قصص تحكيها شهرازاد لأختها دنيازاد بحضرة الملك شهريار. .
قِصَص ألف ليلة وليلة من خغتارات النثر الشعبي، تشمل عدة قصص تحكيها شهرازاد لأختها دنيازاد في معل أقيم بين يدي الملك شهريار. .
قِصَص ألف ليلة وليلة بجموعة ما حكيتها شهرازاد، لدى الملك شهريار، لأختها دنيازاد ويغلب عليها تأثير الخيال الشبعبي. E)

Görüldüğü üzere قصص kelimesinin harekelenmesinde bu hususun göz önünde bulundurulması oldukça makul görünmektedir. Benzer durumlarda da aynı yöntemin izlenmesi uygun olacaktır.

2015-YDS İlkbahar 75. soru B seçeneğindeki “ الأفا تكافح الآفات الزراعية وخاصة المنة cümlesinde geçen المنة kelimesi yaprak biti anlamına gelip nadiren karşılaşılan sözcüklerden biridir. Birçok şekilde okunabilecek kelimenin المنّ şeklinde harekelenmesi faydalı olacaktır.

Aynı şekilde 2015-YDS Sonbahar 43-46. sorulara ait paragrafta yer alan مهرطقة kelimesi ile 47-50. sorulara ait paragrafta yer alan مصعع kelimesi çok kullanılan kelimeler değildir. Kanaatimizce kullanımı nadir bu tarz kelimelerin harekelenmesi daha uygun olacaktır.

Yine 2014-YDS Sonbahar 57. soru C seçeneğindeki “أن المشاركين يختارون من قبل وزارات المالية أو الاقتصاد" ifadesinde geçen مِنْ مِبِل sözcülinde tarafindan, aracıliğğyla anlamında kullanılan bir bağlaç olup harekelenmesi durumunda مِنْ قَبُُْ zarfıyla karıştırılmasının önüne geçilecektir. Nitekim 2016-YDS-İlkbahar 47-50. soruların metninde قبئ zarfının harekelendiği görülmektedir.

\section{5. Şedde}

Aynı soru içerisinde bazı kelimelerde şedde kullanılmış bazılarında ise kullanılmamıştır. Örneğin,

2013-YDS İlkbahar 5. Soru:

------ مستشار الملك عن آرائه الإصلاحية واستنكر الفساد ----- في القصر.
A) عرّب - الواقع
B) عبّر - الموجودة
أفصح - المتفشي C)
D) تحدث - العادي
E) باح - السائد 
Yukarıdaki soruda görüldüğü üzere عبّرَ عرّب fiillerinde şedde konulmasına rağmen ve المتفشّي kelimelerinde ise şedde konulmamıştır. Hangi kelimelerde şedde kullanılması gerektiği konusunda bir birlik sağlanması kaçınılmazdır. Şedde elif lâmdan sonra gelen harflerde konulmamalı, kelimede aynı harfin tekrarı durumunda ise okuyuşu kolaylaştırmak için konulmalıdır.

Bazen de sorularda şedde elifin üzerine konmaktadır. Örneğin 2014-YDS Sonbahar 47-50. sorulara ait paragrafta عelimesinde şedde elif üzerine konulmuştur. Bu kelimede şeddenin elif üzerine değil, lâm üzerine konması gerektiği kanaatindeyiz. ${ }^{7}$ Bu durum sınav sorularında sehven ortaya çıkmış olsa bile sınavın önemi bu tür hataların da azaltılmasını zorunlu k1lmaktadir.

Ayrıca şeddesiz okunduğunda yanlış anlaşılma ihtimali olan kelimelerde şedde kullanılması okuyucuya yardım edecektir. Örneğin 2013-YDS İlkbahar 3. soruda yer alan if şراء ifleklinde okunduğunda başka anlamlara gelmektedir. Bu yüzden konulan şedde anlamı netleştirecektir.

Yaygın kullanımlarına binaen إن، أن، كل، ثم، حتى gibi şeddeli okunan kelimelerde şedde

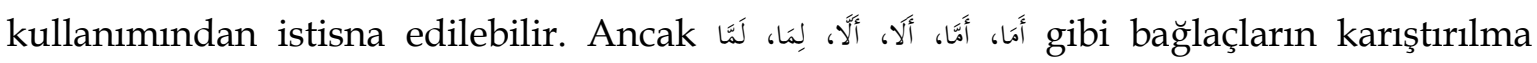
ihtimallerine karşın harekelenmesi adaylar için yararlı olacaktır.

Nâk1s-1 yâî ve lefîf fiillerin ism-i mef' ûllerindeki yâ harfi daima şeddeli olur.8 Dolayısıyla bu kelimelerin de şeddelenmesi faydalı olacaktır. ${ }^{9}$

Sorulara bakıldığında belli düzeyde harekeleme yapıldığı görülmektedir. Ancak bu harekelerin belli bir esas paralelinde kullanılmadığı göze çarpmaktadır. Hareke kullanımının yukarıda zikredilen esaslar nazar-1 itibara alınarak yapılması daha yerinde olacaktır. YDS Arapça sınavında belli standartlar çerçevesinde sınırlı düzeyde hareke kullanımının ilkesel olarak benimsenmesi gerektiği düşünülmektedir.

\section{Yazım Hataları}

Sorular incelendiğinde azımsanmayacak oranda yazım hatalarının olduğu göze çarpmaktadır. Böylesine önemli ve ciddi bir sınavda sıfır veya sıfıra yakın yazım hatasının olması icap etmektedir. Yazım hatalarını ortadan kaldırmak veya minimize etmek için daha çok sayıda uzmanın soru metinlerini okuması sağlanabilir.

\footnotetext{
7 Wikipedia, “علامة التشكيل" (Erişim 05 Eylül 2021).

8 Hamlâvî, Şeze'l-arf, 67; Râcihî, et-Tatbîku's-sarfî, 82; Tural, Temel Sarf Bilgileri, 196.

9 Günday, "Arapça-Türkçe Leksikografiye Dair Bir Tenkit Yazısı", 158.
} 


\section{1. Çok Kullanılan Edatlardaki Yazım Hataları}

gibi edatlarda lâ harfi ayrı yazılması gerekirken bitişik yazılmıştır.

2017-YDS İlkbahar 29. soru E seçeneğindeki “لذلك لابد من تجنب الوجبات الكبيرة والكحول قبل النوم" cümlesinde لا ند ifadesi bitişik olarak yanlış yazılmıştır.

2015-YDS Sonbahar 22-26. sorulara ait paragrafta “" ".... لاسيما مدنية اليونان والفرس والهنود.." ifadesinde سيما sözcüğü bitişik olarak yanlış yazılmıştır. Yine aynı sınavın 51-54. sorulara ait paragrafta da "........... لاسيما في جانبه "السيمانتي" أي الدلاليما ifadesinde ayr1 yazılmas1 gerekirken bitişik yazılmıştır.

2015-YDS Sonbahar 51-54. sorulara ait paragrafta “.... kismindaki hemze-i istifhâmiye bitişik yazılması gerekirken ayrı yazılmıştır.

"يدعي الكثيرون أنه لولم تنته المظاهرات لكانت النتيجة أسوأ. 2015-YDS İlkbahar 66. sorunun C seçeneğindeki ifadesinde harfleri ayrı yazılması gerekirken bitişik yazılmıştır. Aynı hata 67. sorunun C seçeneğinde de tekrarlanmıştır.

\subsection{Yâ Harfinin İmlâsı}

Yâ harfi çift nokta ile yazılması gereken yerlerde bazen çift nokta ile yazılmış bazen de terk edilmiştir. Örneğin, 2014-YDS İlkbahar 52. soru D seçeneğindeki “ أنجتمع يشتكى من البخل fiili noktalı yazılması gerekirken noktasız yazılmıştır. Aynı sınavın

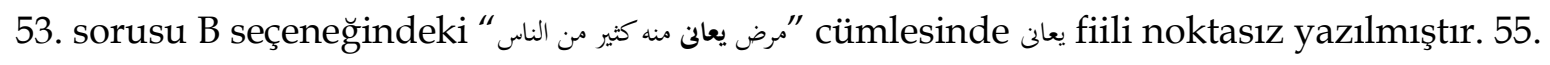
sorunun D seçeneğindeki السخى cümlesinde geçen kelimesi de noktasız yazılmıştır.

Şunu da belirtmek gerekir ki elif-i maksûre ile bitmeyen birçok kelimede de çift nokta kullanılmıştır. Ancak bir birlik ve standart yakalanabilmesi için bu hususa dikkat çekilmiştir.

\subsection{Hemzenin İmlâsı}

YDS Arapça sınavlarında göze çarpan yaygın hatalardan biri de hemzenin yazılışında yapılan hatalardır. Hemze-i vasıl kullanılması gereken bazı yerlerde hemze-i kat', hemze-i kat’ kullanılması gereken bazı yerlerde de hemze-i vaslın kullanıldığı görülmektedir. Aşağıdaki iki başlıkta bu hususlara değinilmiştir.

\subsubsection{Hemze-i Vasılın Hemze-i Kat’ Olarak Yazıldığı Yerler}

2013-YDS İlkbahar 17-21. soruların metninde geçen "اسرق ifadesindeki "إسرق أقل رجاء fiilindeki hemze, hemze-i vasıldır. Ancak soru metninde hemze-i kat' gibi yazılmıştır. 
2013-YDS İlkbahar 35. sorunun soru kökünde "إعلم أن الزهد لا يعني ترك المكاسب" ifadesi yer almaktadır. Bu metindeki اعلم fiili yukarıdaki اسرق fiili gibi sülâsînin emri olup hemze-i vasıl ile yazılmalıdır.

2017-YDS İlkbahar 14. soru kökünde yer alan “ ينص القانون الجديد --- ضرورة إغلاق الموظفين هواتفهم النقالة kelimesi iftiâl babından masdar olup hemze-i vasıl ile yazılması gerekirken hemze-i kat' ile yazılmıştır.

اسم vemze-i vaslın hemze-i kat' olarak yanlış yazıldığ1 yaygın kelimeler ابن kelimeleridir. Bu iki kelimeyle ilgili, sınavlarda çokça hata yapıldığı için burada tek tek örneklendirmek yerine ilgili yerlerin dipnotta verilmesi uygun görülmüştür. ${ }^{10}$

\subsubsection{Hemze-i Kat'ın Hemze-i Vasıl Olarak Yazıldığı Yerler}

2013-YDS İlkbahar 51-54. sorulara ait paragrafta geçen الاسنان kelimesi أفعال vezninden cem-i mükesser olup hemze-i kat' ile yazılmalıdır.

2014-YDS İlkbahar 23. sorudaki الامكانية kelimesi hemze-i vasıl ile yazılmıştır. Bu kelime if âl babından ism-i mensûb olduğu için hemze-i kat' ile yazılmalıdır. Aynı şekilde 2015YDS İlkbahar 78. sorudaki الانتاج kelimesi de if'âl babından masdar olup kat’ hemzesiyle yazilmalıdır. 11

2014-YDS Sonbahar 54. sorunun E seçeneğindeki ثناء kelimesi hemze-i vasıl ile yazılmıştır. Bu kelime hemze-i kat' ile yazılması gereken kelimelerden olduğu için أثناء şeklinde yazılmalıdır.

2016-YDS Sonbahar 29. sorudaki الانفاق kelimesi, soru kökü ve A seçeneğinde hemze-i vasıl ile yazılmışken B seçeneğinde hemze-i kat' ile doğru yazılmıştır. أفنال vezninden cem-i mükesser olan bu kelimenin hemze-i kat' ile yazılması gerekmektedir. Aynı soru içinde aynı kelimenin iki farklı şekilde yazılması göze çarpmaktadır.

2018-YDS İlkbahar 65. soru E seçeneğindeki اعتقد fiili, hemze-i vasıl ile yazılmıştır. Bu fiil muzâri birinci tekil şahıs olup أعتقد şeklinde hemze-i kat’ ile yazılmalıdır.

\footnotetext{
10 Örnekler için bk. 2014-YDS İlkbahar 66, 77 ve 78. soru, 2014-YDS Sonbahar 64. soru, 2015-YDS Sonbahar 4750. soruların metni ve 49. sorunun maddesi. Ayrıca bk. Aktaş, "YDS Arapça Üzerine Eleştirel Bir Değerlendirme", $162 \mathrm{vd}$.

11 Aynı kelime 2018-YDS İlkbahar 2. soruda da yanlış yazılmıştır.
} 


\subsection{Med/Uzatma Hatas1}

2013-YDS İlkbahar 55. soru A seçeneğinde yer alan الأسيوي kelimesi hemze-i kat' ile yazılmıştır. 2018-YDS İlkbahar 75. soru A seçeneğinde ise الآسيوية şeklinde medli yazılmıştır. Hâlbuki آسيا kelimesinin ism-i mensûbu olan bu kelimelerin الآسيوي/الآسيوية şeklinde medli yazılması daha uygundur. ${ }^{12}$ En azından bu tür kelimelerde bir yazım birliği sağlanmalıdır.

\subsection{Yabancı Kelimelerdeki Yazım Tutarsızlıkları}

2015-YDS İlkbahar 35. soru B seçeneğindeki “إثر جلب المستوطنين الأوروبيين أعدادأ كبيرةً من الكلاب من أوروبا" cümlesinde الأوروبيين kelimesinin yazımında râ' dan sonra vâv harfi kullanılmıştır. Aynı şekilde 2015-YDS İlkbahar 75. soru E seçeneğindeki " ورصدت سبع خنافس من النوع الأكثر شيوعاً في أوروبا" cümlesinde أوروبا kelimesi de râ'dan sonra vâv harfi getirilerek yazılmıştır. Ancak 2018-YDS İlkbahar 53. soru B, C ve D seçeneklerinde, 2018-YDS Sonbahar 28. soru kökünde aynı kelimeler ş الأورب/أورب/الأوربية sınavda bu ve benzeri kelimelerde bir yazım birliğinin benimsenmesi oldukça lüzumludur.

2014-YDS İlkbahar 22-26. sorulara ait paragrafta geçen استراتيجي kelimesi hemze-i vasıl ile yazılmış, 2013-YDS İlkbahar 13. soru E seçeneğinde ise إستراتيجيات ş̧eklinde hemze-i kat' ile yazılmıştır. Oysa yabancı bir isim olan bu kelimenin hemze-i kat' ile yazılması daha münasiptir. Kanaatimizce bu tarz kelimelerin yazımında bir birlik sağlanması, tutarlılık sağlayacak ve kafa karışıklığını giderecektir.

\subsection{Gözden Kaçan Yazım Hataları}

$\mathrm{Bu}$ başlık altında soru hazırlama ve incelemede dikkatsizlikten kaynaklanan bazı hususlar tespit edilerek aşağıya çıkarılmıştır:

2013-YDS Sonbahar 49. soru kökünde "----"يقول النص أعلاه إن-" ifadesi yer almaktadır. Ayn1 sorunun E seçeneğinde de “"إنه يساعدنا علم المنطق يساعدنا في التمييز بين الخير والشر cümlesi bulunmaktadır. إن إنه يساعدنا ile devam edemeyeceğinden bu kınra cümın açık bir hata olduğu kolaylikla fark edilebilmektedir.

2014-YDS İlkbahar 56. soru D seçeneğindeki “كامنة في حسن استعمال الوقت وجودة الإتتفاق" ifadesinde şeklinde yanlış yazılmıştır.

2014-YDS İlkbahar 77. sorudaki “....الذين kelimesi görüldüğgü gibi الذيع şeklinde yanlış yazılmıştır.

12 2015-YDS İlkbahar 35. sorunun A seçeneğinde de أسيوية kelimesi medsiz olarak hatalı yazılmıştır. 
2015-YDS İlkbahar 73. soru B seçeneğindeki “ توصل العلماء إلى أن الإدمان على استخدام كومبيوتر له علاقة بالشعور بالجوعز. cümlesinde بالجوع بالجوعز şeklinde yanlış yazılmıştır.

2015-YDS Sonbahar 36. soru D seçeneğindeki “ب "بل أتبع ما اقرحتَ عليّ وأترك ما تعودتُ عليه cümlesinde

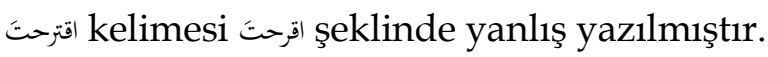

2017-YDS Sonbahar 50. soru D seçeneğinde الزعفران kelimesi الزغفران şeklinde yanlış yazılmıştır.

2017-YDS Sonbahar 56. soru A seçeneğindeki “ الذكاء الاصطناعي الذي من شأنه أن يقضي على البشرية بسبب

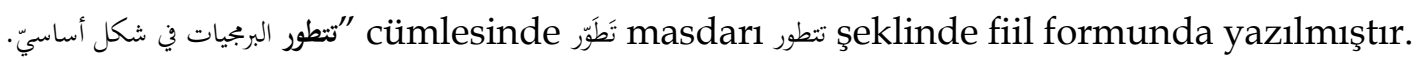

2018-YDS İlkbahar 54. soru D seçeneğindeki “ لأنه تُكن من بناء أكبر عدد من الجوامع والجسور في فترة السلطان

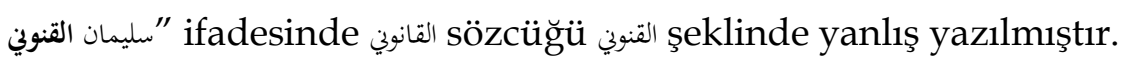

2018-YDS İlkbahar 54. Soru C seçeneğindeki “ بسب اطلاعه على العمائر الأووربية والسلجوقية والفنون المختلفة

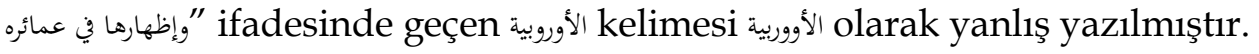

"شارك الوزيرُ الملكَ في السلطة أن يكون أبناؤه مجحوبين عن السياسة. “2018-YDS İlkbahar 70. soru D seçeneğindeki ifadesinde geçen بحوبين kelimesiminde yanlış yazılmıştır.

2018-YDS İlkbahar 80. soru kökünde “.......بالقرب من الحدود اليمينية السعودية بوجود منتزهات طبيعية... ifadesinde yer alan اليمنية sözcüğü اليمينية şeklinde yanlış yazılmıştır.

Yukarıda zikredilen hataların sehven yapıldığı düşünülmektedir. Bu tür hataları asgariye indirmek için soru hazırlayan ve inceleyen uzmanların son derece dikkatli olması kaçınılmazdır. Sınava giren aday sorularda hata olma ihtimalini pek göz önünde bulundurmadığ 1 için, psikolojik olarak yanlış yazılan kelimelere de anlam yükleme yoluna gidebilmektedir. Bu bakımdan incelemelerin daha da titizlikle yapılması yararlı olacaktır.

\section{Dilbilgisel Hatalar}

Soru metin ve seçeneklerine bakıldığında bazı gramatik hataların olduğu fark edilmektedir. Tespit edilen bazı dilbilgisel hatalar şunlardır:

"ألا تلاحظ أن زياد ينفق أموالا كثيرة في الأيام الأخيرة؟ 2013-YDS İlkbahar 65. sorudaki diyalogda yer alan cümlesinde geçen زياد kelimesi, أنّاد 'nin ismi olduğundan nasb konumundadır. Bu nedenle şeklinde mansûb olduğuna delâlet eden elif ile yazılmalıdır.

2015-YDS İlkbahar 27. soru E seçeneğindeki “بلديل إن إذين أسسوا العمران ومصروا بلدان sözcüğü مصروا fiilinin mef' ûlün bihi olarak nasb konumundadır. Bu kelimenin ya البلدان veya يلبانًا şeklinde yazılması gerekmektedir. 
2018-YDS İlkbahar 39. sorudaki “مائة وخمسة وسبعين مليون"... ifadesinde yer alan مليون kelimesi sayının temyizi konumundadır. 11-99 arası rakamların temyizi müfred mansûb geldiğinden bu kelimenin مليونً şeklinde nasb hâli ile yazılması icap etmektedir.

YDS gibi önemli bir dil sınavında dilbilgisi hatalarının yapılması sınavın ruhuna uygun düşmemektedir. Soru hazırlayan ve inceleyen uzmanların bu konuda son derece dikkatli olmaları elzemdir.

\section{4. Çeviri Hataları}

Tüm yıllara ait çeviri sorularına yakından bakıldığında "soru maddesinde yer alan cümlenin birebir çevirisi"nin yapıldığı görülmektedir. Bu bağlamda çevirisi istenen sorunun seçeneklerinde eksik veya fazla kelime bulunan şı aday tarafından elenmektedir.13 ${ }^{13}$ Ancak aşağıda örnekleri verilen sorularda bu hususa yeterince dikkat edilmediği anlaşılmaktadır.

2015-YDS İlkbahar 41. Soru:

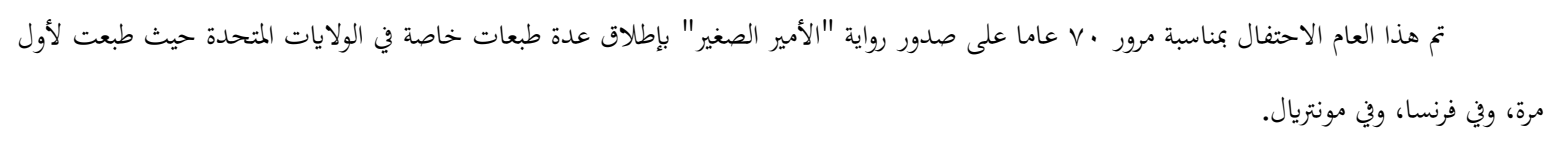

A) Küçük Prens'in ilk yayımlandığı yerler olan Birleşik Devletler, Fransa ve Montreal'de bu yıl düzenlenen, romanın 70. yılı etkinlikleri, çıkarılan birkaç özel baskıyla sona erdi.

B) Küçük Prens'in yayımlanışının üzerinden 70 yıl geçmiş olması dolayısıyla, bu yıl Fransa'da, Montreal'de ve romanın ilk kez yayımlandığı Birleşik Devletler'de birkaç özel parti verildi.

C) Küçük Prens'in 70 yıldır sürmekte olan kutlamaları, bu yıl Fransa'da, Montreal'de ve ilk kez yayımlandığı Birleşik Devletler'de yapılan birkaç özel baskıyla tamamland1.

D) Küçük Prens'in ilk yayımlandığı Fransa'da, Montreal'de ve Birleşik Devletler'de düzenlenen birkaç özel 70. yıl kutlama etkinliği, bu yılki kutlamalarla tamamlandi.

E) Küçük Prens'in yayımlanışının 70. yılı Fransa'da, Montreal'de ve romanın ilk kez yayımlandığı Birleşik Devletler'de, birkaç özel baskı çıkarılmak suretiyle bu yıl kutlandi.

Türkçe çevirisi istenilen bu cümlenin doğru cevabı, cevap anahtarında E seçeneği olarak verilmiştir. Oysa “Küçük Prens'in yayımlanışının 70. y1l1” عناسبة مرور • ع عاما على صدور رواية ifadesini tam olarak karşılamadığı düşünülmektedir. Zikredilen Arapça ifade “Küçük Prens romanının yayımlanışının üzerinden 70 yıl geçmiş olması dolayısıyla"

13 İbrahim Özay, Açıklamalı Örneklerle Kpds Arapça Soru Bankası (Ankara: Asil Yayın Dağıtım, 2007), 67. 
şeklinde olmalıdır. Soru kökündeki Arapça cümlenin tam çevirisi de "Bu yıl Küçük Prens romanının yayımlanışının üzerinden 70 yıl geçmiş olması dolayısıyla, ilk kez yayımlandığı yer olan Birleşik Devletler, Fransa ve Montreal'de birkaç özel baskı çıkarılarak kutlama yapıldı." şeklinde olmalıdır. Ayrıca metinde geçen ülke isimlerinin, metindeki sıra dikkate alınarak çevrilmesi daha uygun görülmektedir.

2015-YDS Sonbahar 40. soruda “Dünya Sağlık Örgütü, Ebola salgınının önümüzdeki birkaç ay yayılmayı sürdürmesini ve Ebola virüsünün bulaştığı insan sayısının yirmi bine yükselmesini beklemektedir." ifadesinin Arapça çevirisi sorulmaktadır. Doğru cevap da aşağıdaki ifade olarak verilmiştir:

$$
\text { تتوقع منظمة الصحة العالمية استمرار تفشي وباء إييولا في الأشهر القادمة وازدياد أعداد المصابين بذذا الفيروس إلى عشرين ألف شخص. }
$$

Görüldüğ̈ü üzere birkaç kelimesi çeviride yansıtılamamıştır. Cümledeki الأشهر kelimesinden önce بعَ sözcüğünün eklenmesinin çeviriyi daha güzel hâle getireceği mülâhaza edilmektedir.

2018-YDS Sonbahar 37. soru

$$
\text { بينت دراسة موسعة أجراها فريق من العلماء البريطانيين أن الناس يصبحون أكثر سعادة عندما يقتربون من سن السبعين. }
$$

A) İngiliz bilim insanlarından oluşan bir ekip, yetmiş yaşına yaklaşan insanların ne kadar mutlu oldukları üzerine kapsamlı bir araştırma gerçekleştirdi.

B) İngiliz bilim insanları, yetmiş yaşına yaklaşan insanlar üzerinde yaptıkları kapsamlı bir araştırmanın sonucundan oldukça mutlu olduklarını açıkladılar.

C) İngiliz bilim insanları tarafından yürütülen kapsamlı bir çalışma, insanların yetmiş yaşına yaklaştıklarında daha mutlu olduklarını ortaya koydu.

D) İngiliz bilim insanları, insanlar üzerinde yaptıkları kapsamlı bir araştırmada, bu kişilerin yetmiş yaşına yaklaştıkları için daha mutlu olduklarını ortaya koydu.

E) İngiliz bilim insanlarından oluşan bir ekip tarafından yürütülen kapsamlı bir çalışma, insanların yetmiş yaşına yaklaşmaktan oldukça mutlu olduklarını gösterdi.

Görüldüğüu üzere فريق kelimesi çeviride yansıtılamamıştır. Sorunun doğru cevabı olan C seçeneğindeki "İngiliz bilim insanları tarafından yürütülen kapsamlı bir çalışma" ifadesinin "İngiliz bilim insanlarından oluşan bir ekip tarafından yürütülen kapsamlı bir çalışma" ifadesi ile değiştirilmesi daha uygun görünmektedir. Öte yandan doğru olarak verilen seçenekte ekip kelimesi yer almadığı için E seçeneği adaylar tarafından doğru cevap olarak görülmektedir.

\section{Yabancı Dil Seviyesini Ölçmek İçin Uygun Görünmeyen Sorular}

Yabancı dil sınavlarının amacı adayın dil seviyesini belirlemek olduğuna göre sorular, adayın bilememesi için hazırlanmış olduğu izlenimi vermemelidir. Aşağıdaki 
sorularda adayın cevabı bilmesinin ölçülmesinden çok bilememesi için hazırlanmış gibi görünmektedir.

2015-YDS İlkbahar 4. Soru

قد تولى تنظيم الشبيبة ومظاهرات معادية للاستعمار ---- باستقلال بلده.
A) في أندية
B) بالنداء
C) يناديه
D) منادياً
E) منتدياً

Bu soruda boşluğa gelebilecek kelimeler için şıklarda sadece aynı kökten türeyen sözcükler verilmiştir. Soruda adayın aynı kökten türeyen bütün kelimeleri bilmesi mi yoksa boşluğa gelebilecek uygun kelimeyi bilmesi mi ölçülmektedir? Bu durum tam anlaşılamamaktadır. Şıklarda aynı kökten türeyen en fazla iki kelimenin kullanılması daha uygun görünmektedir.

2013-YDS Sonbahar 18. Soru

الهندية التي (18) -...--- فيضم المعرض صورًا متنوعة قام بتصويرها كابا، تعود إلى فترة بقائه في إسبانيا أيام الحرب الأهلية، وحتى الحرب العالمية الثانية، وانتهاء بالحرب الصينية
A) ألقى
B) قتي
C) لاقى
D) التقى
تلقى

2017-YDS Sonbahar 6. Soru

الانصهار، علمياً، هو ظاهرة موجودة فعلاً، وفيزيائياً، هو تحول المادة من الحالة الصلبة إلى الحالة السائلة بسبب ---- حرارة شديدة.
A) اعترضها على
B) تعارضها مع
C) إعراضها عن
D) تعرضها لـ
E) عارضها بـ

2018-YDS Sonbahar 7. Soru عندما نقرأ الشعر الجاهلي ---- علينا فهم قسم غير قليل منه، وأكثر ما تعود هذه الصعوبة إلى غرابة ألفاظه.
A) يصاعب
B) يتصاعب
C)
D) يصعب
E) تتصاعب

Yukarıdaki sorularda ise kelimenin hem isim hem de fiil olarak değişik bablardan kullanımları seçeneklerde verilmiştir. Adayın boşluğa gelecek kelimeyi bilip bilmediği mi yoksa bu kökten türeyen isim ve fiilleri bilip bilmediği mi ölçülmektedir? Şıkların bu şekilde verilmesi adayın doğru cevabı bilememesinin istendiği gibi bir durum oluşturmaktadır. Şıklarda başka kökten türeyen ancak boşluğa getirilmeye uygun gibi görünen kelimelerin kullanılması bu izlenimin ortadan kaldırılmasını sağlayacaktır. 
2018-YDS İlkbahar 15. Soru

في عالم سحري وأجواء حالمة، افتتح ---- معرض الأسماك الذهبية في العاصمة اليابانية طوكيو، حيث سعى أكواريوم طوكيو لجعل الزيارة متعة للعين.
A) آخرا
B) مؤخرة
C) تأخيرا
D) مؤخرا
E) آخرة

Yukarıdaki soruda da ısrarla aynı kökten türeyen kelimeler seçeneklerde yer almıştır. Adaya sanki sözlüğü ezberlemiş gibi muamelede bulunulmaktadır. Oysa şıklarda aynı kökten türeyen kelimeler değil çeldirici olarak başka kökten türeyen kelimelerin kullanılması sınavın ruhuna daha uygun görünmektedir.

\section{6. Şekilsel Kusurlar}

Bazı paragrafların iki yana yaslı olduğu bazılarının ise olmadığı tespit edilmiştir. Zaman zaman kelimeler arasında abartılı boşluklar yer almaktadır. ${ }^{14}$

Şekilsel uyumsuzluklar bu tarz bir sınavın ciddiyetine yakışmamakta olup bu kusurların giderilerek soru kitapçığına estetik bir görünüm kazandırılması daha güzel olacaktır.

Öte yandan bazı paragraf soruları oldukça uzun bir şekilde yer alırken bazıları ise kısadır. Paragraflar için bir standart belirlenmeli ve metinler birbirine yakın bir hacimde olmalıdır. Paragrafların 100-120 kelimeden oluşturulması önerilmektedir. Örneğin, 2014YDS Sonbahar sınavındaki metinlerin uzunluğu diğer sınavlara göre daha uygun görünmektedir. Yapılacak sınavlarda bu hususların göz önüne alınması sınavı daha iyi bir hâle getirecektir.

\section{Sonuç ve Öneriler}

YDS Arapça sınavlarında imlâ hataları, hareke, şedde, cezim, med gibi yanlış kullanımlar ile bazı biçimsel kusurlar hemen her sınavda göze çarpmaktadır. Tenvin, şedde ve hareke kullanımında belli kurallar çerçevesinde birlik sağlanamadığı görülmektedir. Örneğin tenvin zaman zaman sözcüğün sonundaki elifin üzerine konulmuş, bazen de eliften önceki harfin üzerine yazılmıştır. Çoğunluğu elif üzerinde görünmektedir. Tenvinin kullanımında tutarlılık ve birlik sağlanabilmesi için iki yoldan biri tercih edilmelidir.

Arap dilinde sonunda elif olan sözcüklerin büyük bir kısmı üstün tenviniyle okunmaktadır. Arapça yabancı dil sınavlarında da hemen hemen buna benzer bütün kelimelere tenvin konulmaktadır. Kelimenin sonundaki elif zaten bu duruma işaret ettiği için, bu tenvinin okuyucuya fazla bir katkı sağlamadığı söylenelebilir. Bu sebeple bu tür kelimelerin sonunda tenvin kullanılmamalıdır. Eğer tenvin kullanılacaksa da yukarıda değinildiği gibi bir tutarlılık içerisinde konulmalıdır. Ayrıca nâkıs fiillerin ism-i fâillerinde

14 Örneğin bk. 2015-YDS İlkbahar 44. soru, 2017-YDS İlkbahar 55-58. sorular, 2017-YDS İlkbahar 73. soru vs. 
esre tenvini konulması adayın sözcüğü doğru okumasına katkı sağlayacağı ve yanlış okumaların önüne geçeceği düşünülmektedir.

Bazı sorularda sülâsî malum fiillerin harekelendiği diğer bir kısmının ise harekelenmediği göze çarpmaktadır. Bu tür fiillerin hangi ölçüte göre harekelendiği tam olarak anlaşılmamaktadır. Malum sülâsî fiilleri harekelemenin okuyucu açısından fazla bir faydası görülmemektedir. Meçhul fiillerin bazı yerlerde harekelendiği bazı yerlerde ise harekelenmediği görülmektedir. Oysa meçhul fiillerin harekelenmesi, malum fiillerin harekelenmesine göre adaya daha fazla yardımcı olacaktır. Bununla beraber mezîd bablardan gelip sülâsî ile karışması mümkün olan fiillerin harekelenmesinde fayda mülâhaza edilmektedir. Bu da en çok if âl babında ortaya çıkmaktadır. Bu yüzden mezîd bablardan özellikle de if' âl babından gelen fiillere hareke konulması önerilmektedir.

Mezîd babların ism-i fâil ve ism-i mef' ûl formunu birbirinden ayıran temel ölçüt sondan önceki harfin harekesidir. İsm-i fâil olan kelimede kesrenin, ism-i mef' ûl olan kelimede ise fethanın konulması adayları ikileme düşmekten kurtaracağı ve süre yarışında kendilerine hız kazandıracağı düşünülmektedir.

Birden fazla biçimde okunmaya müsait olan veya az kullanılan sözcüklerin harekelenmesinde de fayda mülâhaza edilmektedir.

Sınav sorularında aynı soru içerisinde bile bazı kelimelerde şedde kullanıldığı bazılarında ise kullanılmadığı tespit edilmiştir. Şeddenin kullanılacağı kelimelerde bir birlik sağlanması gerekmektedir. Şedde elif lâmdan sonra gelen harflerde konulmamalı, muzaaf fiiller gibi kelimede aynı cinsten iki harf bulunması durumunda okuyuşu kolaylaştırmak için kullanılmalıdır.

Sorularda zaman zaman şeddenin elifin üzerine yazıldı̆̆ı bazen de eliften önceki harfin üzerine yazıldığı görülmektedir. Şeddenin eliften önceki harfin üzerine yazılması önerilmektedir. En azından ikisinden biri tercih edilerek bir tutarlılık sağlanmalıdır. Ayrıca nâkıs-1 yâî ve lefif fiillerin ism-i mef' ûllerindeki yâ harfi daima şeddeli olarak okunur. Bu yüzden bu sözcüklerin de şeddelenmesinde fayda mülâhaza edilmektedir.

Sorular incelendiğinde belli oranda harekelemenin yapıldığı müşahade edilmektedir. Ancak kullanılan bu harekeler için herhangi bir standart belirlenmediği anlaşılmaktadır. YDS Arapça sınavlarında belli standartlar çerçevesinde sınırlı hareke kullanımının prensip olarak benimsenmesi gerektiği düşünülmektedir. Hareke kullanımının yukarıda zikredilen esaslar dikkate alınarak yapılması daha uygun gibi görünmektedir.

Sorulara bakıldığında az sayılmayacak miktarda yazım hatalarının olduğu da tespit edilmiştir. Bu tür mühim ve ciddi bir sınavda yazım hatalarının asgariye indirilmesi gerekmektedir. Bu tür hataların ortadan kaldırılması veya minimize edilmesi için daha çok sayıda uzmanın soruları incelemesi önerilmektedir. Çünkü sınava giren aday sorularda 
hata olma ihtimalini pek göz önünde bulundurmadığı için, psikolojik olarak yanlış yazılan sözcüklere de anlam yükleme yoluna gidebilmektedir.

YDS Arapça sınavlarında bazı dilbilgisi hataların da bulunduğu tespit edilmiştir. $\mathrm{Bu}$ tür hatalar sınavın ruhuna uygun düşmemektedir. Soru hazırlayan ve inceleyen uzmanların bu konuda son derece dikkatli olmaları elzemdir.

Çeviri sorularına genel olarak bakıldığında soru maddesinde yer alan cümledeki her kelimenin çeviriye yansıtıldığı görülmektedir. Ancak bazı sorularda bu durum göz ardı edilmiştir. Bu yüzden çevirisi istenen sorunun şıklarında eksik veya fazla sözcük bulunan seçenek aday tarafından elenmektedir. Bu açıdan bu tür sorularda genellikle yapıldığı gibi çevirisi istenen cümledeki kelimelerin, doğru seçenekte verilen cümleye birebir yansitılması daha uygun olacağı düşünülmektedir.

Bazı sorularda, sorunun seçeneklerinin tamamında aynı kökten türeyen kelimelerin verildiği tespit edilmiştir. Ancak bu durum, sorunun tam olarak neyi ölçtüğünü göstermemektedir. Burada adayın uygun sözcüğü bilip bilmediği mi yoksa bu kökten türeyen isim ve fiilleri bilip bilmediği mi ölçülmektedir? Seçeneklerin bu şekilde verilmesi adayın doğru cevabı bilememesinin istendiği gibi bir izlenim oluşturmaktadır. Seçeneklerde başka kökten türeyen ancak boşluğa getirilmeye uygun gibi görünen sözcüklerin kullanılmasının bu durumu ortadan kaldıracağı mülâhaza edilmektedir.

Yukarıda belirtilen hususlar çerçevesinde bir soru hazırlama ve inceleme rehberi oluşturulması ve bu rehberin, soru hazırlama ve incelemede görev alan uzmanlara ulaştırılması tavsiye edilmektedir. Eğer bu tür bir rehber varsa bu hususların da rehbere eklenmesinin uygun olacağı düşünülmektedir.

\section{Kaynakça}

Aktaş, Osman. "YDS Arapça Üzerine Eleştirel Bir Değerlendirme". Bozok Üniversitesi Illahiyat Fakültesi Dergisi 19/19 (Haziran 2021), 147-167. https:// doi.org/10.51553/bozifder.873097

Günday, Hüseyin. “Arapça-Türkçe Leksikografiye Dair Bir Tenkit Yazısı: Serdar Mutçalı'nın Arapça-Türkçe Sözlük Örneği”. Uludağ Üniversitesi İlahiyat Fakültesi Dergisi 21/2 (Haziran 2012), 141-197.

Hamlâvî, Ahmed. Şeze'l-arffî fenni's-sarf. Riyad: Mektebetü'l-maârif, 2001.

Harder, Ernst. Gaspey-Otto-Sauer Metodu: Modern Arapça Grameri. çev. Ekrem Sarıkçığlu. İstanbul: Otağ Yayınları, 1982.

İbn Cinnî, Ebü'l-Feth Osmân b. Cinî el-Mevsılî. Şerhu't-Tasrîfi'l-mülûkî. thk. Dîzîrîh Sakkal. Beyrut: Dârü'l-fikri'l-Arabî, 1419/1998. 
ÖSYM. "YDS Çıkmış Sorular". Erişim $04 \quad$ Eylül 2021. https://www.osym.gov.tr/TR,15073/yds-cikmis-sorular.html

Özay, İbrahim. Açıklamalı Örneklerle Kpds Arapça Soru Bankası. Ankara: Asil Yayın Dağıtım, 2007.

Râcihî, Abduh. et-Tatbîku's-sarfî. Beyrut: Dârü'n-nehdati'l-Arabiyye, 1393/1973.

Tural, Hüseyin. Temel Sarf Bilgileri. İstanbul: Ensar Neşriyat, 2011.

Wikipedia. "علامة " 2021. https:/ / ar.wikipedia.org/w / index.php?title=eملامة_التشكيل\&oldid=53662220 